Dossiê: Religião e Saúde - Artigo original

\title{
Em busca de uma teologia pública da saúde
}

\author{
Searching for Public Health Theology
}

Alex Villas Boas *

\begin{abstract}
Resumo
A proposta de uma teologia pública da saúde visa ao diálogo entre antropologia teológica e antropologias médicas e da saúde, de modo a ampliar a percepção da saúde, não somente como fato, mas como valor. Mesmo num Estado laico, suas tradições religiosas possuem hermenêuticas de saúde, ao interpretar a doença e a morte com razões religiosas distintas, ora conflitantes, ora cooperativas com as ciências da saúde. Ampliar essas hermenêuticas religiosas compondo a sabedoria de vida presente nas expressões religiosas e o conhecimento científico da área de saúde visa a uma cooperação para interesses de bem comum da sociedade civil, como é a questão da saúde. Para essa reflexão, a escola de Cós combina a sabedoria mítica dos asclepíades e a ciência jônia. Os mitos de saúde nomeados no juramento hipocrático pertencem à tradição da teologia poética grega e indicam uma espécie de credo que a medicina hipocrática professa, na qual o médico, além de profissional, também possui fé na vida e exerce o ofício de sacerdote da esperança. Interessa ainda o modo como o a teologia da saúde grega foi recebida pela teologia cristã, e como ambas desconstruíram suas teodiceias. Nessa recepção há um caminho para se pensar uma teologia pública da saúde.
\end{abstract}

Palavras-Chave: Teologia da saúde; Teologia pública; Teologia grega; Hipócrates; Teologia e medicina.

\begin{abstract}
A proposal for a public theology of health aims to dialogue between theological anthropology and medical anthropology in order to increase the perception of health, not only as a fact, but also as a value. Even in a secular state, religious traditions have hermeneutical health in interpreting the phenomena of illness and death with distinct religious reasons. Such hermeneutics could be sometimes conflicting and sometimes cooperatives with practice and Health Sciences. In this case, the theological task aims to expand a health hermeneutics in civil society, in a critical reissue of the relation between religion and health for the common good of the population such as for example, the issue of health. Therefore, Kos school combines the mythical wisdom of Asclepiades and Ionia science. Health Myths named in the Hippocratic Oath belong to the tradition of Greek poetic theology. This reference indicates a kind of credo in which the Hippocratic medicine professes. The doctor as well as a professional expert is also someone who have faith in life and carries the hope priest's office. Also is relevant here how the Greek health theology was received by Christian theology, and how both deconstructed their theodicies. In this reception, there is a way to think a public theology health.
\end{abstract}

Keywords: Health theology; Public theology; Greek theology; Hippocrates; Theology and medicine.

Artigo recebido em 27 de outubro de 2015 e aprovado em 20 de março de 2016.

Agradeço à Fundação de Amparo à Pesquisa do Estado do Rio de Janeiro - Faperj, pelo apoio a esta pesquisa.

* Doutor em Teologia Sistemática (PUC Rio, 2012), professor da PEPG em Teologia da PUC-SP. País de origem: Brasil. E-mail: alexvboas@gmail.com

Horizonte, Belo Horizonte, v. 14, n. 41, p. 89-121, Jan./Mar. 2016 - ISSN 2175-5841 


\section{Introdução}

O presente trabalho é parte de um projeto sobre identidade e alteridade aplicada ao trabalho, realizado na disciplina de Introdução ao Pensamento Teológico na Faculdade de Ciências Médicas e da Saúde da Pontifícia Universidade Católica de São Paulo. A proposta é pensar como o diálogo da antropologia teológica com a antropologia médica ou da saúde poderia auxiliar em "um modo brasileiro de praticar a antropologia médica” e colaborar nas "políticas de saúde brasileiras" (LEIBING, 2012, p. 124), de maneira que as questões da religião e da saúde possam ser cooperativas na elaboração de um "valor saúde". A proposta do curso nas disciplinas de Introdução ao Pensamento Teológico intercala a exposição temática em sala de aula e visitas de campo, de modo especial nos anos de $2014 \mathrm{e}$ 2015, no Centro de Integração da Mulher - CIM (2015), no qual mulheres vítimas de violência doméstica são abrigadas e protegidas legalmente. A presença dos alunos de medicina nesse espaço visava a ampliar a rede de proteção e denúncia contra a violência doméstica, sendo o profissional de saúde um potencial interventor. Nesses espaços, ouvindo-se as vítimas semanalmente, sentiu-se a pertinência de pensar teologias da saúde, gregas, judaicas e cristãs, para entender a cura como ressignificação, e a religião como cooperativa, dada a necessidade das vítimas de recomeçarem a vida após a amarga experiência do absurdo da violência e do fracasso de um projeto. Também ali se evidenciava a profissão médica como vocação. Portanto, constituía parte da proposta a reflexão sobre o sentido da vida e o projeto de vida, espaço em que a cura da pessoa se consolida, em uma busca e realização de sentido. Isso remeteu à necessidade de pensar as raízes míticas do valor saúde na cultura grega, presentes no juramento de Hipócrates, bem como a questão vocacional do médico, apresentada pelo pai da medicina ocidental como caminho de santidade, de modo que esses elementos faziam parte da tarefa de investigar uma teologia grega da saúde. Revisitar os mitos de saúde da tradição grega poético-teológica nomeados no juramento hipocrático visou a resgatar uma sabedoria asclepitana de busca de cura da cultura, sendo Hipócrates um asclepitano, como afirmara Platão (Fedro, 270c), e olvidada pelo historiador 
iluminista.

Sendo expressivas a quantidade e a extensão dos problemas de saúde pública, bem como a capilar presença de uma cultura religiosa no país, é sintomática para a pouca cooperação entre saúde e religião a escassez de uma teologia da saúde e uma antropologia da saúde que façam dialogar suas respectivas epistemologias. Há alguns bons trabalhos em língua portuguesa e que fizeram parte das leituras iniciais do projeto de pesquisa, como a Teologia da saúde, de Francisco Álvarez (2013), que aborda questões de atendimento pastoral nos espaços de saúde (capelania); o trabalho de Martins e Martini intitulado Teologia e saúde (2012), que procura encontrar pontes de afinidade que auxiliam a pensar a vulnerabilidade humana, e também o interessante trabalho de Hermans e Sauvage, Bíblia e medicina (2007), que pensa uma teologia bíblica da saúde.

A concepção de cura foi sofrendo mudanças ao longo do tempo, de modo que tanto a teologia influencia nessas mudanças, quanto estas na teologia. Já na Renascença havia uma preocupação com certa theologia medicalis como cura do espírito do enfermo, marcado pela caducidade do espírito barroco, em que tanto os mitos quanto os personagens da literatura judaico-cristã funcionavam como apoteca spiritualis (DE ANGELIS, 2008, p. 73-97; STEIGER, 2008, p. 99-129). Mas nada se encontrou a respeito de uma teologia asclepitana como base de uma medicina hipocrática, nem mesmo sobre a recepção cristã da síntese da escola de Cós, entre sabedoria asclepitana e ciência jônia, sendo a discussão teológica acentuadamente a respeito do elemento sapiencial, ausente inclusive na literatura médica. Nossa contribuição, se assim se pode chamar, procurou revisitar essa relação que visa a qualificar a percepção tanto do profissional da saúde e do teólogo no que toca à cooperação entre fé e saúde a partir da realidade sofrida dos que solicitam, mais que conhecimento técnico, uma sabedoria e uma sensibilidade proativa no trato com as pessoas, fim último da cura. Tal trabalho investigativo permitiu mapear algumas formas teológicas de pensar a saúde, a fim de iluminar 
temas que podem ser desdobrados, como espiritualidade do paciente e a responsabilidade do tratamento, vocação à medicina, hermenêutica teológica da saúde e superação de visões rígidas, quer de exclusão da religiosidade no tratamento, quer do descrédito nas ciências e no profissional da saúde por parte de algumas mentalidades religiosas. Isso de modo a se ter ferramentas argumentativas que possam motivar o paciente fiel a entender a sua fé como cooperadora do tratamento médico e terapêutico, bem como uma concepção de ensino das áreas de saúde que incorporem as formas de sabedoria religiosas, como parece ter sido feito originalmente na medicina hipocrática.

\section{Da superação de teodiceias a uma teologia pública}

Os fenômenos da doença e da morte fazem parte da tradição filosófica e teológica na questão do Mal, em que uma das formas de intepretação, sobretudo em regimes de teocracia, são as teodiceias ou justificativas teológicas (theós diké) em que as causas históricas são substituídas por causas divinas, oferecendo uma justificativa lógica da tragédia, e até mesmo uma justificativa da injustiça como vontade de Deus. Substituem, assim, a finalidade de teopatodiceias, ${ }^{1}$ sabedoria religiosa enquanto espiritualidade [theós] que, diante das inquietações humanas [pathos], elabora sentidos proativos [diké], autenticamente humanos, como formas de pensar o sentido da religião de modo cooperativo com a sociedade.

Teodiceias tendem a anestesiar a consciência de responsabilidade, infantilizando assim a reação humana às experiências de absurdo ao se acomodar a uma leitura de causalidade divina. Apesar de as teocracias caírem, as teodiceias permanecem por mais tempo no substrato cultural. Cabe como tarefa teológica a superação das formas de teodiceias que justificam as causas históricas com razões

${ }^{1}$ Sobre o conceito de teodiceia e teopatodiceia, cf. VILLAS BOAS, 2014; 2011a; 2011 b.

Horizonte, Belo Horizonte, v. 14, n. 41, p. 88-121, Jan./Mar. 2016 - ISSN 2175-5841 
divinas, oriundas de períodos teocráticos, como é o caso do judaísmo monárquico e do cristianismo imperial, e não raro frequentes na mentalidade religiosa brasileira. A crítica da modernidade à religião incide diretamente sobre as formas de teodiceia que resultam na perda da consciência trágica, não sabendo mais o indivíduo lidar com o sofrimento, na falta de responsabilidade pessoal e anestesiamento social, na medida em que todas as causas têm origem em Deus, fazendo da religião uma ilusão que desvia o olhar diante do absurdo da vida (FREUD, 1927, p. 3-4).

Desse modo, as formas de teodiceia não permitem apreender o sentido mais profundo da percepção de um Mistério como fonte de ressignificação e de enfrentamento, ao colocar tanto a origem da saúde quanto da doença em uma divindade. Tal mentalidade se faz presente, por exemplo, no personagem Pangloss, do Cândido de Voltaire, que adquiriu uma doença transmissível pelo contato com um tripulante companheiro de Cristóvão Colombo, mas que trouxe também "chocolate e cochonilha". Dessa forma, todo mal é condição de um bem, e estabelece exatamente a relação desproporcional do "tamanho do mal" [doença adquirida] com o "tamanho do bem" [chocolate e cochonilha]. Cândido, ao constatar que Pangloss estava em tão "lastimável estado", pergunta-lhe: "Como essa bela causa pôde produzir em vós tão abominável efeito?":

Ó Pangloss! [...] que estranha genealogia! Será que o tronco não foi o diabo? - Absolutamente, replicou o grande homem; era uma coisa indispensável no melhor dos mundos; pois se Colombo não tivesse apanhado numa das ilhas da América essa doença que envenena a fonte geradora, que amiúde até impede a geração, e que é evidentemente o oposto do grande objetivo da natureza, não teríamos o chocolate nem a cochonilha; cumpre observar ainda que até hoje, em nosso continente, essa doença nos é particular, como a controvérsia. (VOLTAIRE, 2003, p. $16-17 ; 22)$.

No que toca à importância e à necessidade de uma teologia da saúde, cabe observar que os fenômenos da doença e da morte estão situados dentro de duas questões fundamentais: uma que é o absurdo do fatídico da doença e sua direção para a morte e a outra é a potencialidade da vida e sua capacidade de resiliência e superação. Nesta, a criação da cultura é um espaço de engendramento de sentido e, 
portanto, um modo de enfrentar e combater o absurdo. No que toca à saúde, a espiritualidade depurada de teodiceias pode ser tanto cooperativa no processo de tratamento e cura, como de responsabilidade na cooperação e elaboração de políticas públicas de saúde, quando a fé passa a ser também uma forma de combate ao absurdo. É nesse sentido que mesmo uma teologia da saúde confessional pode corroborar uma teologia pública da saúde, no sentido de elaborar um "discurso sobre Deus e suas correspondentes crenças, colocado no espaço da sociedade plural” e no "espaço público", podendo ser suas razões "debatidas, enriquecidas, contraditadas ou assimiladas" e assim corroborarem o "interesse público e democrático" de "proteger a sociedade de fundamentalismos e dogmatismos" religiosos e laicos (ANJOS, 2011, p. 127-128). Uma teologia pública da saúde, depurada das teodiceias, visa à cooperação com um interesse de bem comum da sociedade que é o valor saúde, comum inclusive às religiões, que podem cooperar com a necessidade de se repensar as respectivas ações nessa área fundamental.

\section{Elementos para uma teologia da saúde em Hipócrates}

A escola de Cós ganhou grande relevância na medida em que a medicina não era apenas uma profissão, mas um modo de ser que visava ao ideal do homem saudável. Assim a saúde como "força cultural" inicia o conceito basilar dos gregos de paideia, com Hipócrates (JAEGER, 2013, p. 1011-1071). Não é ao acaso que o juramento (orkos) ${ }^{2}$ hipocrático, ao invocar os deuses, evoca uma sabedoria poéticoteológica que indica uma possível espiritualidade na base de sua concepção de medicina e saúde. Contudo, uma primeira dificuldade para reconhecer a teologia da saúde em Hipócrates pode advir de uma perspectiva iluminista anacrônica aplicada aos gregos, que acaba por classificar a escola de Cós dentro da separação entre mitos e logos, sendo este um "milagre grego" (BURNET, 1994, p. 75), em

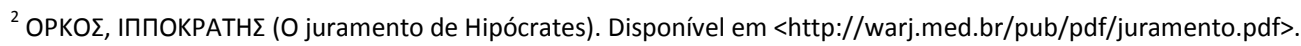


detrimento do suposto "período de trevas" da época homérica e hesíodica. Os diálogos de Platão também podem ser um grave fator para essa dissociação da escola de Cós de sua matriz teológica, sendo que o logos platônico relega o mito ao ostracismo acadêmico, substituindo a sabedoria poética do mito pela verdade da dialética e ocupando o papel da "teologia homérica” (AUBRETON, 1968, p. 223). O interesse de Platão parece se reduzir à techné médica de Hipócrates como modelo de uma techné para a retórica, comparando a capacidade do médico em "dar saúde e força” com a do filósofo em dar "discursos e argumentos legítimos” (Fedro, 268a272c).

\subsection{Sapiência e ciência: dos santuários de Asclépio à Escola de Cós}

Antes mesmo de Platão apresentar o maravilhoso como princípio da filosofia, sendo a admiração ou o espanto [thaumazein] o início do desejo de pensar (Teeteto, 115d 1-3), o mito já era visto como resposta a esse maravilhoso, uma narrativa fantástica sobre a origem das coisas. Em seu sentido originário, o mito não é invenção, mas "expressão de verdade" e "revelação do sentido das coisas" (JELLAMO, 2005, p. 3). Também Aristóteles dizia que "aquele que ama o mito é de certo modo filósofo", por causa da maravilha (dia to thaumazein) que o mito desperta (Metafísica I, 2, 982b 12-13). A posição aqui mantida, nesse ponto, é a mesma de Siqueira Batista, de não haver uma descontinuidade entre a narrativa mítica e o método empírico da medicina hipocrática, mas antes se unem numa "incontestável coalizão" (2003, p. 159s).

A criação do mito é uma tentativa de conferir sentido ao mundo, e assim oferecer um "modo de ser", um habitus vivido e celebrado, que vai engendrando uma cultura. Gusdorf, por exemplo, em Mito e Metafísica, à luz da etnologia e do pensamento existencial, propõe "uma leitura em continuidade do progresso do pensamento humano", considerando a análise dos mitos como "exame das origens do pensamento reflexivo" ou ainda como uma "introdução à ontologia", de modo a 
afirmar que a "consciência filosófica" nasceu da "consciência mítica", uma vez que ambas se constituem como um "corpo de verdades abstratas", "válidas por sobre o espaço e o tempo". O mito é a expressão de quando o habitat humano assume forma mental, no qual "se encontra o homem e seu lugar no mundo". Nesse momento ocorre a mitopoiése enquanto criação do mito que opera como logopoiése, ou seja, criação de sentido. O mito, portanto, define e redefine o habitat humano, enunciando uma ontologia espontânea, em que a consciência humana afirma-se como capaz de intervir no universo. Desse modo, para o homem mítico, "o mito não é um mito, mas a própria realidade" e está ligado ao "primeiro conhecimento que o homem adquire de si mesmo" e "o mundo, até então privado de sentido, adquire sentido", de onde se desdobra a técnica, a previsão de fenômenos como "modo de ser das coisas" (BUCHER, 2003, p. 95-106; GUSDORF, 1980, p. 17-24). O "mythos é uma palavra que circunscreve e fixa um acontecimento" (VAN DER LEEUW, 1940, p. 131) doador de sentido a um mundo que se manifesta como absurdo, o que torna a vida humana possível como cocriadora da realidade. O pensamento mítico é engajado com a realidade de modo visceral, é um pensamento não alegórico, mas “tautegórico", que remete à própria realidade (SCHELLING, 1945, p. 239).

Os mitos, dito desta maneira, são "princípios de realidade para a vida humana" e sustentam o rito, que por sua vez coloca o mito em "regime de ação" ou, ainda, "o rito coloca o mito em ação", suscitando-o e repetindo-o no presente e levando aquele que celebra o rito a participar da vida do mito, que, por sua vez, prescreve um "protótipo de conduta eficaz". As estruturas do mito não possuem tanta validade histórica quanto ontológica. O tempo do mito é sempre o tempo presente e, ao mesmo tempo, o tempo primordial (GUSDORF, 1980, p. 37-40). Essa "metafísica primitiva" se dá ao fato de que "um objeto ou um ato não se torna real senão na medida em que ele imita ou repete um arquétipo”. De sorte que a realidade se alcança exclusivamente por repetição ou participação. O que não tem um modelo exemplar está "desprovido de sentido", ou seja, "carece de realidade" (ELIADE, 1949, p. 63). É a "experiência primitiva da repetição" dada pelo rito que 
funda a comunidade, ao doar a consciência da realidade abrigada no mito, ou seja, engendra uma cultura como bem comum de um povo. A liturgia da repetição dos ritos conduz a uma repetição da ação que ganha progressivamente consciência do sentido abrigado no rito, e assim se participa do mito em uma lógica de criação continuada. Como já definia Müller, "a mitologia deve o seu nascimento a uma concepção tão poética quanto filosófica da natureza e de seus fenômenos marcantes" (1898, p. 39). Entretanto, quando o mito proposto deixa de ser um princípio de percepção da realidade, os mitos vão sendo reeditados e sofrendo deslocamentos semânticos.

\subsection{O mito de Asclépio e o juramento de Hipócrates}

Não raro, pouco se atenta para o fato de se identificar ao menos duas teologias na obra homérica, uma teodiceia que justifica a guerra de Troia por vontade divina, na Ilíada, e outra que se apresenta como "lógica poética" (VICO, 2005, § 144), ou seja, como busca de sentido, presente na Odisseia. Na medida em que o herói descobre na volta para Ítaca o auxílio exclusivo de Atenas em detrimento das teologias de outros mitos, indicando a busca da sabedoria contida numa visão teológica que conjugava uma nova linguagem para uma nova práxis, e que com isso se abre a novos espantos mobilizadores de reflexão (thaumazein) (VILLAS BOAS, 2014, p. 265-277). Tal questão é de suma importância para se considerar a recepção estética dos deuses invocados no juramento da escola de Cós, a saber Apolo, Asclépio, Higyeia e Panaceia e como, portanto, poder-se-ia identificar uma influência teológica na doutrina hipocrática.

Entre as quatro divindades citadas no orkós hipocrático, Apolo é o mais importante, porém, essa divindade sofre profundas transformações, sendo o Apolo homérico da Ilíada apenas um "deus de santuário” e uma “divindade provinciana” (BRANDÃO, 2013, v. I, p. 143-144). O fato de ser o deus de Troia, a cidade derrotada na famosa guerra contra os aqueus (1300 a 1200 a.C.), pode ter sido um 
dos fatores para o deslocamento semântico teológico que irá resultar no Apolo póshomérico do Oráculo de Delfos. Em todo caso, a transformação de Apolo indica uma "longa evolução da cultura e do espírito grego", especialmente da “interpretação dos mitos” e consequentemente uma mudança teológica que amalgama várias funções míticas de outras divindades, como por exemplo, ocupa o lugar de Hélio e passa a ser visto como o "deus da luz", "ideal de cultura e sabedoria", e "realizador do equilíbrio e da harmonia dos desejos", reorientando-os para uma "espiritualização progressiva" que culmina no "desenvolvimento da consciência" a partir do "conhece-te a ti mesmo" (gnothi s'autón) do Oráculo de Delfos (BRANDÃO, 2013, v. II, p. 86), centro [mítico] do mundo grego, a Jerusalém grega, fixada pela divindade. Esse Apolo pós-homérico será visto como chave de leitura para os mitos homéricos a partir de Platão, que o chama de “exegeta nacional”, pois "é a Apolo, deus de Delfos, que compete estabelecer as leis mais importantes, as mais belas e as primeiras entre todas" (pátrios eksegétes cf. República, 427, b-c). É uma divindade essencialmente reconciliadora, que visa a unir os contrastes da pólis pela sabedoria (sophrosyne), diferente de Dionísio, que provoca a mudança, segundo a concepção platônica.

Assim há que se considerar que o Apolo do juramento hipocrático (460377/70 a.C.) não é o homérico, mas este da época de Platão (428/27 a 348/47 a.C.), e, portanto, invocado como deus que concede luz e inspira sabedoria. Apesar do deslocamento semântico de Apolo, um traço permanece de Homero a Delfos, ou seja, é um deus que cura, como indica o epíteto Apolo Paiéon, 3 dedicado a ele na Ilíada: "Paiéon/num benéfico bálsamo [phármaca] banhou-lhe a chaga/e o curou [katathetós], pois não era de estirpe mortal” (Canto V, 401-402).

Dado o deslocamento semântico, o remédio [phármacon] do Apolo hipocrático e sua cura [katathetós] estão ligados ao “conhece-te a ti mesmo" que

\footnotetext{
${ }^{3}$ Paiéon ou Paiawon era uma divindade cultuada em Cnossos sob a dominação grega, que a llíada chama de Péan. Ao mesmo tempo Paiéon é a canção sagrada que apazigua a cólera de Apolo, relação que parece ter origem na tradição minoica. O Péan cretense, enquanto hino e dança, foi transferido no início do século VII de Creta para Esparta, tornando-se o hino cultual de Apolo, entendido ainda como o próprio canto de cura (SANTOS, 1998).
} 
purifica a alma da ignorância. E nesse sentido podem ser lidas as demais invocações. Asclépio, de médico que "vale por muitos homens" (Ilíada, Canto XI, 514-515), que visitou Troia com seus dois filhos, Podalírio e Macaon, e Patroclo, amigo de Aquiles (Ilíada, 729-732), passa a herói, sendo filho de Apolo e uma mortal chamada Corônis, que, temendo a infidelidade de Apolo, se une a um mortal, Ísquis, e junto com ele é morta a pedido de Apolo. O filho, retirado por uma “cesariana umbilical”, é educado por Kheiron, possível abreviatura de kheirourgós, aquele que "trabalha com as mãos", um "cirurgião". Kheiron tinha duas notas significativas: era um médico ferido e um Centauro. No massacre dos Centauros por Héracles foi ferido por uma flecha, gerando uma ferida incurável, e consequentemente eterna, pois era imortal, sendo filho de Crono. Essa condição de médico ferido o ajudava a compreender seus pacientes, com compaixão. Em uma troca com Prometeu, que lhe concede o direito à morte, Kheiron sobe aos céus, sendo essa sua condição de animal e homem e sua ascensão, a síntese do humano que evolui espiritualmente. Asclépio aprendeu de Kheiron a amizade pelos homens, a música, a moral, e sobretudo a medicina, e a aperfeiçoou a tal ponto que aprendera a ressuscitar os mortos, motivo pelo qual Zeus o fulminou, a pedido de Plutão. Porém, por sua imensa importância fora divinizado. De médico exímio, passa a herói (Argonautica de Apolônio de Rohdes) e depois a mito do deus médico "filantropíssimo", por devolver a vida aos já tidos como mortos. Dos quatro filhos, apenas as filhas, Panaceia e Higyeia, são citadas no juramento. A teogenia asclepiana, enquanto mitopoiése dos deuses, indica em suas divindades um modo de ser que evoca a busca da cura de todas as doenças [Panaceia], e não somente o fato saúde, mas o valor saúde [Higyeia] deve ser cultuado. 


\subsection{Os santuários de Asclépio e a medicina hipocrática}

Os asclepíades constituíam uma espécie de comunidade religiosa de sacerdotes médicos que transmitiam sua doutrina de pai para filho nas famílias sacerdotais, mas que passaram em algum momento a iniciados não familiares. Tais sacerdotes habitavam em santuários conhecidos como Asclépeion, dedicados ao deus da cura. Tais santuários e o culto a Asclépio se iniciam no século V a.C. e perduram até o século IV d.C., chegando ao fim com o Cristianismo Imperial.

Após a resistência ao avanço do Império Persa, desde o século VI e a Guerra do Peloponeso no século V a.C., acentua-se o declínio da pólis grega, o que resulta em problemas de alimentação, falta de higiene, e consequente aumento de doenças. Nesse contexto, a religião tradicional também entrava em crise com seus cultos públicos, não sabendo o povo a quem rezar. Cresciam as práticas religiosas de reclusão da sociedade, procurando paz e salvação da alma imortal, como por exemplo o orfismo influenciando pensadores como Pitágoras e Empédocles ou ainda o epicurismo (KOCH, 2012, p. 17). Nesse contexto o culto a Asclépio ganha grande importância e se expande, dando início à concepção de paideia como uma cultura educacional, de onde nasce a medicina de Hipócrates. É sintomático que do século V ao III a.C., o culto de Asclépio tivesse lugar em Atenas, epicentro da crise grega, dada a relação de Asclépio com Apolo. Porém é o santuário de Epidauro, ainda no Peloponeso (cf. Fig 1, 2 e 3), o maior e o mais famoso. Diferentemente de Atenas, fora construído fora da cidade, oferecendo assim condições mais adequadas à saúde. Contudo, ao menos dez outros asclepiai foram construídos na Grécia nesse período, a saber: Corinto, Messene, Pérgamo, Cós, Agrigento, Paros, Delos e Vélia. Os recursos vinham sobretudo da gratidão daqueles que haviam obtido a cura. No Asclépeion de Pérgamo há a invocação de Asclépio Soter, considerado o deus salvador, diferente dos demais, e cuja única atribuição é a cura (KOCH, 2012, p. 12-29). 
Sendo o mito a sustentação do rito, a ação proposta sugere um modo de ser aos fiéis adoecidos, de modo que os ritos visavam àquilo que o mito evocava: a cura. Ao ingressar em um templo de Asclépio, cujos rituais religiosos compreendiam jejuns, dietas, banhos, unções, os doentes deveriam descansar e até mesmo pernoitar, para se colher o relato dos sonhos. Os sacerdotes visitavam os doentes diariamente, e registravam no tholos, uma edificação circular onde se inscrevia o nome dos doentes curados, as doenças que haviam chegado ao templo e a maneira como o doente havia sido tratado (SAGLIO, 1892, p. 470-472). Baseado nas descrições dos sonhos, nos sintomas, na evolução dos sinais e no peso, os asclepíades prescreviam poções de sangrias, cicuta, vomitórios e purgatórios (KOCH, 2012, p. 23-27).

Além do deslocamento semântico de lenda a mito, deslocam-se também as práticas de cura para a proposição de um modo de ser: começa-se a conceber a saúde como um valor cultural e consequentemente se engendra aí o ideal helênico do homem saudável. Há uma ontologia da saúde nos mitos medicinais que propõem a cura da cultura, do modo de pensar, com a nooterapia, em que ocorria a metanoia, a transformação dos sentimentos, mudando a atitude do doente em relação não somente à doença, mas à vida. Essa atitude do paciente era doada pelo médico, que assumia para si o modo de viver que prescrevia. Assim deveria jurar o médico de Cós: "Com santidade [agíos] e pureza [osíos] conservarei minha vida e minha arte” (Orkós, 4). O juramento de Hipócrates é uma chave de leitura dos “pensamentos santos" prescritos aos fiéis doentes do santuário, pois acreditam na Panaceia e na Higyeia, ou seja, na cura de todas as doenças e na criação de uma cultura que promova o valor saúde, fé que repercute em uma atitude de enfrentamento da doença. Um dos fatores para se afirmar que uma cultura educacional helênica (paideia) tem início com os médicos ou, mais precisamente, os asclepíades se dão pelo fato de que em seus santuários, dada a ideia de nooterapia, o tratamento inclui a oferta de festivais de teatro, de dança, de canto, devendo ter em todo Asclepeion um anfiteatro, pois era necessária a transformação/cura dos pensamentos e dos sentimentos. 
O historiador iluminista preferiu acentuar o contato de Hipócrates com a ciência jônia, dado o fato de que os escritos do Corpus hippocraticum estão em jônio, sendo o grego de Cós de matriz dórica, e dada a menção que Hipócrates chega a fazer de autores jônios como Alcméon de Crotona e Empédocles de Agrigento (FRIAS, 2005, p. 23-31). Entretanto, a identidade de Hipócrates como um asclepíade é apresentada por Platão (Fedro, 270c). Essa dicotomia iluminista dificulta a percepção de que a adoção de uma filosofia da natureza em busca de um princípio de atuação da natureza [arché], antes de ser uma dissociação da teologia, constitui um avanço teológico que elabora uma nova soteriologia (FERRY, 2006, p. 28). A ordem do mundo mantida por Zeus e seu panteão é relida como a beleza do Cosmos no qual a reverência aos deuses [theoi] é deslocada para a contemplação da beleza do Mistério do universo, que está todo inter-relacionado (mais tarde será chamado "ontologia"). Desse modo, a contemplação [theoria] visa a encontrar correlações de causa e efeito e assim reproduzir a beleza do macrocosmo do Universo no microcosmo da vida. Ademais, o pensamento jônio em busca de uma compreensão da physis, ao inspirar a ideia de lei natural, em Aristóteles endossa a escravidão (Política, I, 5, 1254a, 14-18), ao passo que a atitude hipocrática de tratar com igualdade "livres e escravos" (Orkós, 2) está muito mais próxima à filantropia dos mitos de Asclépio e à santidade do pensamento asclepíade, bem como ao discernimento para evitar o mal e a injustiça, guardar seus segredos, mesmo com esses escravos que, juntamente com as mulheres, eram tidos por nada (Orkós, 6;7). A elaboração de uma literatura para uma população leiga, precursora de uma medicina preventiva, pode ser vista nesse mesmo viés. Também há de se considerar que o ofício de médico exigia condições favoráveis, e buscando Hipócrates viver seu ofício de modo itinerante, não teria essa motivação de sua vocação médica uma correlação com a expansão dos santuários de Asclépio? Motivo pelo qual teria ido para Tessália em sua maturidade, região do Asclepeion de Epidauro, o maior santuário e consequentemente o maior acervo de informações médicas (tholo)? Se arriscaria a hipótese de que o Santuário de Cós (366/5 a.C.) teria sido o pioneiro dessa síntese entre ciência jônia e sabedoria poético-teológica asclepiana. 
Certo é que a filosofia jônia oferece a possibilidade de um "olhar dirigido" à observação clínica que melhor capacita a tratar das doenças como sendo de origem humana, 4 e não divina. Porém isso em nada exige a recusa de uma teologia asclepíade, mas antes resulta em um modo de pensar a saúde a partir de uma consciência teológica que afirma a fé na vida, uma esperança de poder se aproximar um pouco mais da utopia da cura de todas as doenças (Panaceia), dimensão que retroalimenta a ciência investigadora como horizonte de busca sempre mais arredio para instaurar o valor da saúde (Higyeia).

\section{A recepção cristã da teologia da saúde hipocrática}

A pesquisa da recepção cristã do pensamento hipocrático teve início com o trabalho de Adolf von Harnack, no século XIX, o primeiro a identificar médicos cristãos [christilichen Ärzten], a começar do evangelista Lucas; Alexandre médico, o Frígio (177); uma escola cristã de medicina galena em Roma (cc. 200); Proculus, uma espécie de curador cristão, mencionado por Tertuliano; Julio Africano (cc 225); Epifanios, médico e bispo palestino (cc 300); Basilio de Ancira, Aécio, o ariano, Aglaofon e Parata (cc. 300); Zenóbio de Sidon, sacerdote e médico que sofreu o martírio de Diocleciano (303); Teódoto, médico e bispo da Laodiceia (cc 305), Flavius, gramático e escritor médico; Hierakas, um monge egípcio e médico (ambos cc 305); Eusébio, médico e bispo de Roma (cc 310). Harnack dá especial atenção os irmãos médicos, Cosme e Damião, patronos dos médicos e farmacêuticos, que estudaram medicina na Síria e morreram como mártires. Menciona ainda o grande médico cristão sírio, no século IX, Abu Zaid Honain ben Ishaq, em Bagdá (HARNACK, 1892, p. 38-50).

Há com certeza uma teologia da saúde nas Escrituras hebraicas, em que o vocábulo shalom concentra em sua densidade semântica a concepção de saúde e de paz. A paz é fruto de uma saúde de vida, que coincide com a busca de um modo de

\footnotetext{
${ }^{4}$ A concepção de Hipócrates como médico do corpo, em detrimento da medicina da alma de Platão (FRIAS, 2005, p. 80), é resultado de uma separação dos escritos médicos do Corpus Hippocraticum em relação à teologia asclepíade.
}

Horizonte, Belo Horizonte, v. 14, n. 41, p. 89-121, Jan./Mar. 2016 - ISSN 2175-5841 
ser justo. A volta do coração à justiça traz saúde e paz para o povo: "Porque te restaurarei a saúde, e te curarei as tuas chagas, diz o Senhor" (Jer 30,17). Aquele que busca a justiça encontrará a saúde da paz: "Eis que eu trarei a ela saúde e cura, e os sararei, e lhes manifestarei abundância de paz e de verdade” (Jer 33,6), e por isso “a língua do sábio é saúde [marepe]” (Pr 12, 18). A sabedoria sirácida constitui um avanço na teologia hebraica da saúde $(\operatorname{Ex} 12,12)$ em seu contato no exílio com o helenismo, em que a cura é proveniente de Deus, porém através do médico, seu agente (Sir 38,1-5). Contudo, com a teocracia saduceia, a teologia do puro e impuro se apresenta como um retrocesso no judaísmo pós-exílio, em que a doença é vista como origem do pecado, provocando exclusão social.

Nas Escrituras cristãs a saúde é também desejada por Deus, e com isso há a afirmação do valor saúde: "Senhor, se quiseres, tu podes me curar [...] Quero! Sê limpo [katharísthéti]! (Mt 8,2-3). Entretanto, há uma sabedoria em apontar o caminho curto da cura, extraordinário que comunica a presença do Mistério, especialmente para aqueles em que a doença era sinal de exclusão dos lugares tidos como sagrados. A cura aqui indica que Deus ama tais pessoas e sobretudo se faz presente no momento imediato do sofrimento. Mas há também o caminho longo da cura, que se dá como mudança de mentalidade, à qual os asclepíades também chamavam de metanoia, uma cura da percepção da vida, do modo de ser, da cegueira da autossuficiência e da descrença na vida. As doenças, por mais que sejam curadas em algum ponto da trajetória da vida, não dispensam a condição humana de se encontrar com elas novamente. A conversão dessa mentalidade autossuficiente, não raro motivo de fracasso e sofrimento, para o "voltar a ter saúde” coincide em última instância com o "passar a viver apesar de”. O convite de "Toma tua cruz, e segue-me" (Mc 10,21; Mt 10,28) está diretamente ligado ao "caminho de felicidade" [Felizes... cf. Mt 5-8]. Também Jesus "sarava os que necessitavam de cura" e "falava do Reino de Deus". A cura vinha no desejo de seguimento (Lc 9,11), e se manifesta na "saúde do todo" [holo-klérian] (At 3,16). Esse aspecto coincide com a leitura que Platão faz de holos como método de Hipócrates, de que não se pode curar as partes sem compreender a saúde no 
"todo", e o todo [holos] é visto na relação de harmonia entre o microcosmo da alma e o macrocosmo do Universo (Fedro, 268e). Lucas indica, com isso, uma cura da pessoa, a descoberta de um sentido maior para a vida, apesar da doença, e até mesmo, descoberta na ocasião da doença, como com a conversão de Paulo (At 9, 119). Com efeito, enquanto a teologia da saúde está abrigada em uma sabedoria de vida, a teologia neotestamentária é muito mais próxima da teologia asclepíade que da teodiceia farisaica.

Já a recepção da medicina hipocrática se dá conforme a recusa ou assimilação da helenização, consequentemente entre uma visão de cristianismo como cultura superior, como alguns chamaram, ou como cultura alternativa, como aqui se prefere, na qual se realizam cristãmente os grandes ideais da cultura grega (FERNGREN, 2009, p. 29-57; JAEGER, 2014, p. 9-22). Tal recepção sofreu, assim, inúmeras interpretações entre posições de convergência (VERHEY, 1984, p. 157170) ou incompatibilidade (VEATCH; MASON, 1987). Tertuliano, por exemplo, vê Hipócrates como representante de uma escola de pensamento grego, e não como um médico somente. Assim, apesar de ter uma consciência ética, não era tão superior quanto a ética cristã, uma vez que se viam como "médicos de almas", e não somente de corpos (VEATCH; MASON, 1987, p. 88), posição que não é isenta de uma influência platonizante do cristianismo (FRIAS, 2005, p. 79-83). Conhecida também é a crítica do retórico Arnobius de Sicca no século IV, em sua obra Adversius nationes, em que apresenta uma defesa do cristianismo como prova de sua conversão sincera ao Bispo de Sicca. Nessa obra elabora uma espécie de disputa taumatúrgica entre Cristo e Asclépio, de modo a apresentar a compaixão do Cristo com todos aqueles que sofrem, e o maior número de milagres como distintivo das curas do deus pagão, além de dizer que a cura de Asclépio se reduz ao corpo, mas permanece a doença da alma (Adversius nationes, 7, 44). Contudo, após explicitar a sua visão de superioridade do Cristo, reconhece a medicina como um presente de Deus e apropriada para os cristãos, e com isso aponta para o diagnóstico hipocrático de atribuir a doença às causas naturais, e não divinas (FERNGREN, 2009, p. 44-51). Ainda mais veemente é a crítica de Lactâncio ao apresentar 
Asclépio como "arquedemônio" (Divinae institutiones, 2, 16, 12), o que revela a influência de Asclépio no mundo antigo. Jerônimo ridiculariza os sacerdotes de Asclépio, que não curam dos pecados, e com isso curam o corpo, mas permanece a dor. Portanto, o verus medicus ou ainda o medicus et medicamentum é a santidade de Cristo e não a santidade de Hipócrates (ARBESMANN, 1954, p. 6).

Com efeito, na medida em que os mitos gregos foram sendo relidos a partir da concepção de mysteria do cristianismo primitivo (RAHNER, 1954, p. 16-59), a devoção a Asclépio foi sendo substituída pelo tema do Christós Iatrós ou Christus medicus, presente já em Inácio de Antioquia (Eph. 7, 2), em que, consequentemente, o epíteto de soter asclepíade também se transfere ao Cristo como em Clemente de Alexandria (Stromata I, 75,2) e em Orígenes, em que a medicina grega é a "parábola mais clara do Evangelho em ação" (DÖNERMANN, 2003, p. 80-84; 121-159). Efrem, o Sírio apresenta o Paraíso como "medicina da vida" em contraponto ao "veneno da morte" apresentado pela Serpente, o que poderia indicar uma crítica ao culto asclepíade. Contudo, parece não ver problema em utilizar termos da teologia asclepíade como therapeuo ou iaomai (SHEMUNKASHO, 2004, p. 15). Também os autores capadócios revisitam a relação de saúde do corpo e da alma no cristianismo como paideia alternativa. Com isso, a medicina hipocrática vai sendo recebida, porém reformulada sua base teológica asclepíade, vista como protocristológica, constituindo assim sistemas complementares, nos quais a ciência jônia e a espiritualidade da saúde são preservadas na teologia e na liturgia do cristianismo primitivo. Também Agostinho usa a categoria Christus medicus, já uma forte devoção na África desde Tertuliano, em sua soteriologia como metáfora da redenção (ARBESMAN, 1954, p. 1-28). O Cristo magister humilitatis é também o medicus humilis (AUGUSTINUS, Sermones, 22,1), contrapondo a humildade do Cristo Salvador e a pretensão do Médico Divino, Asclépio [Soter], podendo curar a cultura grega da doença da hybris, do desejo de ser como deus, que resultou na ganância e conduziu à corrupção das virtudes. A doença grega está em sua cegueira de sequer ver a humildade como virtude (AUGUSTINUS, Civitas Dei, XIV-XVIII; XXVIII). A 
assimilação do epíteto soter de Asclépio para o Christus medicus passa pelo mesmo processo de amálgama do mito de Hélios (KNIPP, 1998, p. 3-22; DAREMBERG; SAGLIO, 1892, p. 470-472), assimilando não só uma ideia, mas uma soteriologia e iconografia medicinal-farmacológica (HERZOG, 1994, p. 434 - cf. Fig. 3, 4 e 5).

Contudo, é com o cristianismo imperial que os Asclépeion são destruídos, como relata Eusébio de Cesareia, enaltecendo a ação de Constantino de eliminar o santuário da Cilícia e com isso qualquer vestígio da "antiga loucura" (Vita Constantini, 3, 56). Com a imperialização do cristianismo prevalece a atitude de hostilidade e, desse modo, a espiritualidade da saúde vai sendo alocada nos mosteiros que concentram tarefas hospitalares. Desde então, o juramento de Hipócrates sofre uma adaptação cristã no século XI (VEATCH, 2000, p. 28; VERHEY, 1984, p. 151-181;).5 Há também uma versão judaica, conhecida como juramento de Asaph, Ben Berachyahu (séc. VI) (ROSNER; MUNTNER, 1965, p. 317-320).

Apesar do diálogo entre fé e razão empreendido por Tomás de Aquino, que vê a saúde na "ordem dos fins" [ordine filium] e a medicina na "ordem das causas eficientes" [ordine causarum efficientium], sendo que o "desejo da saúde tem por causa a vida” (Suma Teológica II, q. 87, ad. 3), no século XVIII a teologia da saúde cristã volta a ser alocada em uma teodiceia segundo a proposta de Leibniz (16461716), que será criticada veementemente por Voltaire. O mesmo acontece na teologia judaica, expressa no juramento de Asaph: "Confie no Senhor nosso Deus [...] Aquele que mata e faz viver, que fere e que cura" (VEATCH, 2000, p. 57-58).

Apesar de a produção de teodiceias ser uma tentação constante das religiões, tais formas de justitificação religiosa nunca são totalmente homogêneas e, portanto, não estão isentas de resistências e tensões. As teodiceias começam a ruir na medida em que as práticas empregadas por um grupo religioso se distinguem das práticas desejadas pelas mesmas, mesmo permanecendo por mais tempo

\footnotetext{
${ }^{5} \mathrm{O}$ texto se encontra na Biblioteca Vaticana (Urbinus 64mss). Disponível em University of Minnesota <http://www1.umn.edu/phrm/oaths/oath3.html>.
}

Horizonte, Belo Horizonte, v. 14, n. 41, p. 89-121, Jan./Mar. 2016 - ISSN 2175-5841 
resquícios dessa linguagem em novas práticas, como é o caso da teologia da saúde elaborada, ainda que embrionariamente, por Santo Inácio de Loyola. Há um aprofundamento da concepção cristã de cura da pessoa, para a cura da liberdade e concomitantemente a cura da comunidade. Assim, apesar dos resquícios de linguagem de teodiceia, o modo de conceber e a importância dada à saúde nada têm a ver com a concepção de que a origem da doença ou da saúde provém de Deus, mas é a saúde do corpo e da alma que glorifica a Deus. Isso se dá dentro de uma responsabilidade compartilhada, elencando-se quatro sujeitos de ação nas Constituições da Companhia de Jesus: a própria pessoa, o superior, o médico e a comunidade.

A própria pessoa é convidada a ver a saúde como um dom de Deus e cuidar do corpo como responsável primeiro é, inclusive, uma tarefa de sua espiritualidade, que deve

fazer progredir e avançar em espírito e virtude no caminho do divino serviço, olhando para a saúde e forças corporais requeridas para trabalhar na vinha do Senhor. Por isso se tratará em primeiro lugar do que se refere ao espírito, e depois do que se refere ao corpo. (Capítulo I, Conservação quanto à alma e ao progresso nas virtudes, [243] 1)

E, desse modo, deve saber dosar o cuidado com as coisas espirituais e o cuidado com o corpo, estando atento a qualquer sinal de mau funcionamento:

Apesar da preocupação exagerada com os cuidados do corpo ser repreensível, o devido cuidado em usar os meios de conservar a saúde e as forças físicas, para o divino serviço, é de louvar e a todos se pede. Por isso, quando sintam que alguma coisa lhes faz mal, ou que outra lhes é necessária, quanto a alimento, vestuário, habitação, ofício ou trabalho, bem como qualquer outra coisa, devem avisar o Superior (Capítulo II, Conservação do corpo [292,1]).

E por isso mesmo é bom que "algum exercício corporal em proveito de um e outro é de ordinário útil para todos, mesmo para os que devem aplicar-se ao trabalho intelectual" ([298] 4). Do mesmo modo deve moderar as penitências de maneira que não prejudiquem a saúde e ainda observar as recomendações médicas 
em geral, como respeitar "o tempo de sono, [que] segundo parece, deve ser geralmente de seis a sete horas" ([301]). A vontade de Deus se encontra em responsabilizar-se pela própria saúde, “para que Deus Nosso Senhor seja mais glorificado em nossas almas e nossos corpos” ([300] 5).

Por sua vez, compete ao superior, enquanto autoridade que tem a função de ajudar a discernir a vontade de Deus, "defender a saúde" dos membros da comunidade ([424] 5) e providenciar que haja na casa alguém com "superintendência de tudo que diz respeito à saúde para ajudar a conservá-la naqueles que a possuem" e "restabelecê-la nos que estão enfermos" ([303] 6). Por isso mesmo, "é bom não sobrecarregar ninguém de tanto trabalho físico que se afogue o espírito e se prejudique o corpo" ([298] 4). O superior é o responsável por fazer com que a saúde seja vista como necessária para a missão, e se o ingressante não tiver saúde a ponto de ser inapto a "enfrentar as exigências" da missão, "podese despedi-lo, mas com a devida caridade”. Porém, “depois dos primeiros votos e antes dos últimos”, ninguém pode ser despedido "nem por falta de saúde física ou psíquica, se a enfermidade tiver sido contraída por descuido da Companhia ou pelo trabalho nela realizado", mas antes deve ser acolhido pela comunidade, como um $\operatorname{dom}\left[34,1^{\mathrm{o}}\right.$ e $\left.2^{\mathrm{o}}\right]$.

A responsabilidade pela saúde, que em última instância é vontade de Deus, é compartilhada com o médico e os enfermeiros que, na ocasião de algum doente na comunidade, se tornam como que os superiores da casa, devendo ser obedecidos como a própria voz de Deus:

Quando alguém está doente há de guardar a obediência com grande pureza, não somente aos Superiores espirituais para que dirijam a alma, mas também, com a mesma humildade, aos médicos corporais $\mathrm{e}$ enfermeiros, para que olhem pelo corpo. Pois os primeiros tratam da plena saúde da alma, e os segundos da perfeita saúde do corpo. ([89] 32).

E, por fim, como sendo de especial importância a comunidade, que além de compartilhar do dever de ajudar a “olhar pela conservação da saúde de cada um” 
([826] 13), deve ter consciência do despojamento que é chamada a ter, pois "nem todos têm as mesmas forças naturais, [e] nem todos têm a mesma saúde física" (Capítulo II, A pobreza e suas consequências [579] M). Consequentemente, o evento da doença é um convite à comunidade em ter disposição para hospedar um membro em condição de doente e cooperar com Deus na sua vontade de que reencontre sua saúde, de modo que todos devem ter uma vida em comum, mas quando alguém necessita de maior cuidado, dar a este mais do que aos outros "por falta de saúde", isso "não se opõe de modo algum à vida comum" (Artigo III, sobre a vida comum, $\left.174,1^{\circ}\right)$.

Se mesmo tomados todos os cuidados preventivos, ainda assim a inevitabilidade da doença se impõe fatidicamente, ela deve continuar sendo vista como um evento que convida a todos a se tornarem agentes de saúde, cada um a seu modo, e ao mesmo tempo um fenômeno que solicita uma revisão do sentido da existência, fazendo repensar o modo de ser. Ou seja, não sendo possível curar a doença, deve-se procurar a cura da pessoa curando-se as relações envolvidas, a cura entendida como ressignificação dessas relações, por ocasião do término da vida daquele que irá partir. Na teologia da sáude inaciana, Deus atua nessa ressignificação. Deus não está na origem da doença, mas, uma vez tendo acontecido, Deus atua, como diria Tomás de Aquino, em causas segundas (ST, q. 117, ad. 1). Nesse caso:

O doente deve, além disso, mostrar grande humildade e paciência para não dar aos que o visitam, e com ele falam e tratam, menos edificação durante a doença do que antes quando tinha saúde, para maior glória de Deus. ([89] 32).

A cura acontece no nível mais profundo quando há a ressignificação do paciente em repensar o que o leva à doença, convidando a encontrar razões mais profundas, tema presente já no Christus medicus de Agostinho, enquanto a humildade [humilitas] é a cura para a ilusão da autossuficiência, ou seja, o problema da hybris grega. Há uma cura da liberdade enquanto disposição para se responsabilizar pela saúde, porque mais consciente. Contudo, há de se considerar 
que certas doenças não são causa de edificação do paciente, como por exemplo quando a doença leva a "perder o uso da razão", em que "não há culpa nem mérito pelo que dizem", ou quando "algum enfermo não for na sua doença tão edificante quanto seria de desejar”. Nesse caso é a comunidade que é curada, quando responde ao chamado de dar um cuidado especial ao doente ou, dito de outra maneira, a cura da comunidade acontece na ressignificação do modo como passa a se relacionar com o doente. Apesar dos cuidados médicos, os demais membros da comunidade devem visitar o doente, e assim a ressignificação acontece, seja pelo paciente, que deve aprender a viver apesar da doença (sem cura), seja sobretudo pela comunidade, que aprende a viver com a doença. Tal qual a doença atinge a comunidade, a cura também é da comunidade, superando a doença, ou descobrindo uma nova forma de viver, postura que leva à criação das Casas de Saúde, para atender de modo melhor tais enfermos, sustentada pelo trabalho da comunidade ([597]). O doente é o Cristo que sofre e a comunidade é chamada a ser o Christus medicus. O hospital é sempre a experiência de devolver o senso da realidade humana, e consequentemente da humildade como cura do narcisismo.

\section{Conclusão}

A doença não é somente um fenômeno biológico, mas existencial, e nessa condição participa da experiência cultural e histórica de uma determinada região e época, assimilando os significados culturais (sentido passivo) e elaborando alguns próprios (sentido ativo) como consciência, mínima que seja, da nova condição vivida. Desse modo, a doença é um evento que exige o discernimento da ação em prol da cura. Entre esses sentidos passivos da cultura, há o desafio da superação das formas de teodiceia. Estas funcionam como anestésicos que desresponsabilizam e dessensibilizam as expressões de fé de suas tarefas de elaboração de sentidos que gerem atitudes proativas. Superadas as formas de teodiceia, a sabedoria presente nas teologias da saúde pode se constituir como 
formas cooperativas dos tratamentos médicos e terapêuticos, pela fé na vida que carregam.

Há nessas sabedorias míticas e narrativas, uma cura [ressignificação] no modo de pensar a vida a partir da doença. Essa é uma contribuição da teologia asclepíade, que o historiador iluminista omite, seja intencionalmente, seja por ignorância epistemológica. Nessa perspectiva, a escola de Cós é uma excelente experiência de unir sabedoria existencial [localizada na hermenêutica dinâmica dos mitos] e ciência [dialogando com a filosofia/ciência jônia], formulando já aí uma teologia da saúde moderna, enquanto à frente de seu tempo. Com a assunção da cosmovisão cristã na cultura grega, a assimilação da síntese hipocrática de uma teologia da saúde dependeu da assimilação da helenização da cosmovisão cristã, até então herdeira da cultura hebraica. Contudo, não houve resistência a uma assimilação científica da medicina hipocrática, mas sim no encontro dessas cosmovisões, em que estava em jogo qual sabedoria de vida seguir. Apesar de a imperialização do cristianismo resultar em cooptação violenta da cultura, como a destruição dos asclepeions, e engendrar um novo processo de teodiceia. Entretanto, à medida que a helenização fora aceita, como nas escolas teológicas da Alexandria e Capadócia, pode-se verificar na teologia da saúde cristã uma continuidade e um avanço da teologia hipocrática, que é pensar a cura da pessoa, para além da doença, enquanto cura da sua liberdade como ressignificação que mobiliza para uma decisão das possibilidades que gerem mais vida, ainda que nos momentos finais, pois a vida pode encontrar sentido no último instante e descobrir que isso foi o suficiente para ter valido a pena viver (FRANKL, 2003, p. 108-113).

Ademais, tanto na figura do Asclépio soter quanto do Christus medicus há uma consciência de cura da cultura, enquanto cura do modo de ver a saúde e a doença. Na nooterapia asclepíade, o médico que deposita fé na vida é também um sacerdote da esperança, que propõe "pensamentos santos", ou seja, um estilo de vida que promove um sentido maior. Na concepção da saúde de Inácio de Loyola, 
chamado por Rahner de "autêntico existencialista moderno" (1965, p. 236), a doença é um fato que não tem origem em Deus, antes é um evento no qual há um chamado de Deus a todos para se responsabilizar, e consequentemente a cura também pode ocorrer na comunidade para além do enfermo. Nesse sentido também há a distinção da concepção de onipotência teológica de que as teologias bíblicas hebraicas e cristãs podem ajudar na superação de uma mentalidade de teodiceia. Distinta da onipotência de Zeus que é arbitrária, a de YHWH se limita ao que é justo, pois Deus não pode ser injusto, e a onipotência cristã é circunscrita no amor: "Deus só pode o que o Amor pode" (VARILLON, 1981, p. 42-44). Desse modo, o poder de amar de Deus se desdobra na sabedoria de salvar ensinando a amar e, por conseguinte, curar ensinando a cuidar do valor saúde, curar a comunidade de seu egoísmo, convidada a se ocupar do irmão doente. Há nas teologias de saúde uma busca de sentido que apreende um "modelo de saúde" a partir de uma consciência teológica, realizado na percepção da "pedagogia divina", quer pelo mito de Asclépio, no qual Hipócrates jura, quer pela Torah, quer pelo mistério de Cristo (ÁLVAREZ, 2013, p. 104), em que cada um colabora a seu modo.

O sentido antropológico da salvação, na medida em que visa a salvar a história da pessoa de uma vida absurda e sem sentido, pode lançar luz sobre a antropologia da saúde de pensar igualmente a cura da pessoa, mais que a doença, e a possível cura da comunidade na doença. Nesse aspecto, verifica-se, nos casos contados pelo neurocientista Oliver Sachs, que o papel do médico impotente diante da doença passa a ser de como ajudar a pessoa a viver apesar da doença (SACKS, 1995), na busca de um sentido maior no qual vale a pena viver, apesar do absurdo que tomou a forma de doença.

Com efeito, as religiões sempre correm o risco e a tentação de elaborar teodiceias que provocam reducionismos de percepção e justificativas de contradições. Entretanto, essas formas de mentalidade religiosa em que as causas fatalistas são atribuídas a uma vontade divina não são em hipótese alguma a forma definitiva ou essencial de uma tradição religiosa. A própria prática significante 
desloca o sentido semântico das linguagens religiosas. Contudo, na medida em que a modernidade se manifesta como crítica às teodiceias, também incorreram no risco de deixar de refletir sobre o papel da religião na sociedade, tornando-se um ponto cego na percepção da realidade. Enquanto tal, pode ser um ponto vulnerável no qual pode-se instalar a manipulação e o abuso da questão religiosa, com interesses escusos de ocupar espaços de decisão política e/ou exploração financeira. Pensar a questão religiosa é uma tarefa também da sociedade, de modo que ela acontece no tecido social e atinge, entre outros fatores, a saúde. Uma tarefa em aberto da cura da cultura contemporânea é reduzir a exploração religiosa da saúde, compondo uma fé e esperança mais lúcidas, juntamente com a adesão responsável ao tratamento, evitando sua evasão por anúncios de pseudocuras, e ampliar a atuação na elaboração de políticas públicas de saúde, aproveitando a contribuição de cada teologia confessional da saúde, pois a oferta de saúde para todos e os que mais necessitam é um desejo tanto de Hipócrates ("em quantas casas eu entrar, entrarei para o benefício dos que sofrem [...] mulheres, homens livres ou escravos" (cf. Orkhós, 6), quanto de Cristo (Eu estive doente e me visitou cf. Mt 25,36). Um modo brasileiro de elaborar políticas públicas de saúde, salvo melhor juízo, passa pelo esforço de cooperação entre comunidades religiosas e profissionais da saúde em elaborar uma hermenêutica da saúde que supere exageros e insuficiências mútuas, de modo que a sinceridade da fé e a eficiência profissional e acadêmica não se vejam como combatentes, mas parceiras diante do valor comum da saúde, e as respectivas implicações políticas e sociais. A isso se presta uma teologia pública da saúde. 


\section{REFERÊNCIAS}

ÁlVAREZ, F. Teologia da Saúde. São Paulo: C. U. São Camilo/Paulinas, 2013.

ANJOS, M. F. Teologia como Profissão: Da Confessionalidade à Esfera Pública. In: SOARES, A.; PASSOS, J. Teologia Pública. São Paulo: Paulinas, 2011, p. 122-133.

ARBESMANN, R. The Concept of Christus Medicus in St. Augustine. In: Traditio: Studies in Ancient and Medieval History, Thought, and Religion, v. 10. New York: Fordham University, 1954, p.1-28.

ARISTÓTELES. Complete works, v.2. Princeton: Princeton University Press, 1984.

AUBRETON, R. Introdução a Homero. São Paulo: Editora da USP, 1968.

AURELII AUGUSTINI. Opera Omnia. Nuova Biblioteca Agostiniana. Roma: Città Editrice. Disponível em <http://www.augustinus.it/.

BRANDÃO, J. Mitologia Grega, v.1 e 2, 25. ed. Petrópolis: Vozes, 2013.

BUCHER, G. Mythopoïése/Logopoïese: Les fins de la Poésie. Cahiers Életroniques de l'imaginaire. Heroïsation et questionnement identitaire em Occident: Mise en place des concepts interdisciplinaires. Univertisté Catholique du Louvain, Belgique, n.1, p.94-106, 2003.

BURNET, J. O Despertar da Filosofia Grega. São Paulo: Editora Siciliano, 1994.

CIM - Centro de Integração da Mulher. Disponível em: < http://www.cimmulher.org.br/> . Acesso em: 29 maio 2015.

CONSTITUIÇÕES DA COMPANHIA DE JESUS e Normas Complementares. São Paulo: Edições Loyola, 2004.

DAREMBERG, C.; SAGLIO, E. (dir.). Dictionnaire des Antiquités Grecques et Romaines, verbete Asklépion, v.1. Paris: Hachette, 1892, p. 470-472.

DE ANGELIS, S. Die Liebeskrankheit und der Eros-Mythos Zur Beziehung von medizinischen und poetischen Texte in der Renaissance. In: PETHES, N.; RICHTER, S. Medizinische Schreibweisen: Ausdifferenzierung und Transfer zwischen Medizin und Literatur (1600-1900). Tübingen: Max Niemeyer Verlag, p. 73-97, 2008.

DÖNERMANN, M. Krankheit und Heilung in der Theologie der fhühen Kircheväter. Tübingen: Mohr Siebeck, 2003.

ELIADE, M. Le Mythe de l'Éternel Retour. N.R.F: Washington, 1949. 
FERNGREN, G. B. Medicine and Health Care in Early Christianism. Baltimore: John Hopkins University Press, 2009.

FERRY, L. Aprender a Viver: Filosofia para os novos tempos. Rio de Janeiro: Editora Objetiva, 2006.

FRANKL, V. Psicoterapia e Sentido da Vida. 4. ed. São Paulo: Quadrante, 2003.

FREUD, S. Futuro de Uma Ilusão. Obras psicológicas completas de Sigmund Freud: edição standard brasileira. Rio de Janeiro: Imago, 1927.

FRIAS, I. Doença do Corpo, Doença da Alma: Medicina e Filosofia na Grécia Antiga. Rio de Janeiro: Editora PUC Rio/São Paulo: Edições Loyola, 2005.

GUSDORF, G. Mito e Metafísica: Introdução à Filosofia. São Paulo: Convivio, 1980.

HARNACK, A. Medicinische aus der ältesten Kirchengeschichte. In: HARNACK, A; GERHARDT, O. Texte und Untersuchungen zur Geschichte der altchristlichen Literatur. Leipezig: Hinrich'sche Buchhandlung, 1892, p. 38-50.

HERMANS, M.; SAUVAGE, P. (org.) Bíblia e Medicina: o corpo e o espírito. São Paulo: Edições Loyola, 2007.

HERZOG, M. Christus medicus, apothecarius, samaritanus, balneator. Motive einer medizinisch-pharmazeutischen Soteriologie. Geist und Leben, München, v. 67, n.6, 1994, p. 414-434.

HOMERO. Ilíada. Texto Bilingue, v.1 e 2. São Paulo: Editora Benvirá, 2012.

JAEGER, W. Paideia: A formação do homem grego. São Paulo: WWF, 2013.

JELLAMO, A. Il Cammino di Diké - L'idea di giustizia da Omero a Eschilo. Roma: Donzelli Editore, 2005.

KNIPP, D. Christus Medicus in der frühchristlichen Sarkophagskulptur Ikonographische Studien zur Sepulkralkunst des späten vierten Jahrhunderts. Brill: Köln, p. 3-22, 1998.

KOCH, S. R. Os Santuários de Asclépio: Expressões Arquitetônicas, Sociais e Religiosas nos Séculos V, IV e III. 117f. 2012. Dissertação (Mestrado). Programa de Pósgraduação em Arqueologia do Museu de Arqueologia e Etnologia da USP- Universidade de São Paulo, São Paulo, 2012.

LEIBING, A. Sobre a Antropologia Médica, e Muito Mais... O corpo saudável e a identidade brasileira. In: SAILLANT, F.; GENEST, S. Antropologia Médica: Ancoragens locais, desafios globais. Rio de Janeiro: Fiocruz, 2012, p. 123-137. 
MARTINS, A; MARTINI, A (org.) Teologia e Saúde: Compaixão e Fé em meio à vulnerabilidade humana. São Paulo: Paulinas, 2012.

MÜLLER, M. Nouvelles Études de Mythologie, Paris: Félix Alcan Editeur, 1898.

PLATÃO. Obras completas. Madrid: Aguilar, 1966.

RAHNER, H. Mythes grecs et Mystére Chrétien. Paris: Payot, 1954.

RAHNER, K. Betrachtungen zum ignatianischen Exerzitienbuch. Münschen: Kösel Verlag, 1965.

ROSNER, F.; MUNTNER, S. The Oath's Asaph. Annals of Internal Medicine, United States, v. 63. n. 2, p. 317-320, 1965.

SACKS, O. Um antropólogo em Marte: sete histórias paradoxais. São Paulo: Companhia das Letras, 1995.

SANTOS, F. B. Canto e Espetáculo em Eurípides: Alceste, Hipólito e Ifigênia em Áulis. 1998. Doutorado (Tese). Departamento de Letras Clássicas e Vernáculas da Faculdade de Filosofia, Letras e Ciências Humanas da USP- Universidade de São Paulo, São Paulo, 1998.

SCHELling, F.W., Introduction à la Philosophie de la Mythologie, VIII, Tomo I. Aubiere: Gallimard, 1945.

SCHOTT, H. Reiligiöse Heilkunde - Christus medicus In Deutsches Ärzteblatt, vol. 101, Medizin Editorial, 2004, p. 28-29.

SHEMUNKASHO, Aho. Healing in the Theology of Saint Ephrem. New Jersey: Gorgias Press, 2004.

SIQUEIRA BATISTA, R. Mito, filosofia e medicina na Grécia Antiga: Relações entre a poesia épica, a filosofia pré-socrática e medicina de Hipócrates. Dissertação de mestrado - Pontifícia Universidade Católica do Rio de Janeiro, Rio de Janeiro, 2003.

STEIGER, J. A. Theologia medicalis und apotheca spiritualis: Zur Intertextualität von medizinischen und theologischen Schreibweisen bei Luther und im Luthertum der Barockzeit In: PETHES, N.; RICHTER, S. Medizinische Schreibweisen. Tübingen: Max Niemeyer Verlag, 2008, p. 99-129.

TOMÁS DE AQUINO. Suma Teológica, v.1, parte 1. São Paulo: Loyola, 2002.

VAN DER LEEUW, G. L'homme primitif et la Religion. Paris: Alcan, 1940.

VARILLON, F. Crer para viver. Edições Loyola, 1991.

Horizonte, Belo Horizonte, v. 14, n. 41, p. 89-121, Jan./Mar. 2016 - ISSN 2175-5841 
VEATCH, R. Cross-Cultural Perspectives in Medical Ethics. London: Jones and Bartlett, 2000.

VEATCH, R. M; MASON, C. G. Hippocratic vs. Judeo-Christian Medical Ethics: Principles in Conflict. Journal of Religious Ethics, v. 15, n. 1, p.86-105, 1987.

VERHEY, A. The Doctor's Oath: a Christian Swearing it. In: SMITH, D. (ed.) Respect and Care in Medical Ethics. Lanham: University Press of America, 1984, p. 151-181.

VICO, G. A Ciência Nova. Lisboa: Fundação Calouste Gulbenbenkian, 2005.

VILLAS BOAS, A. A proposta de uma Teopatodiceia como pensamento poético-teológico Ciberteologia: Revista de Teologia \& Cultura, São Paulo, Edição n. 36, Ano VII, 2011, p. 23-54.

VILLAS BOAS, A. Entre a Teografia e a Teologia In Teografias. Lisboa, 2011, p. 267-287.

VILLAS BOAS, A. Recepção Estética e deslocamento semântico-teológico da obra de Homero. In Revista Brasileira de Literaturas e Teologias - Teoliterária, v.4, n. 7, São Paulo: 2014, p. 265-277.

VOLTAIRE. Candido. São Paulo: Martins Fontes, 2003. 


\section{Anexos}

Fig. 1- Asklepeion de Epidauro

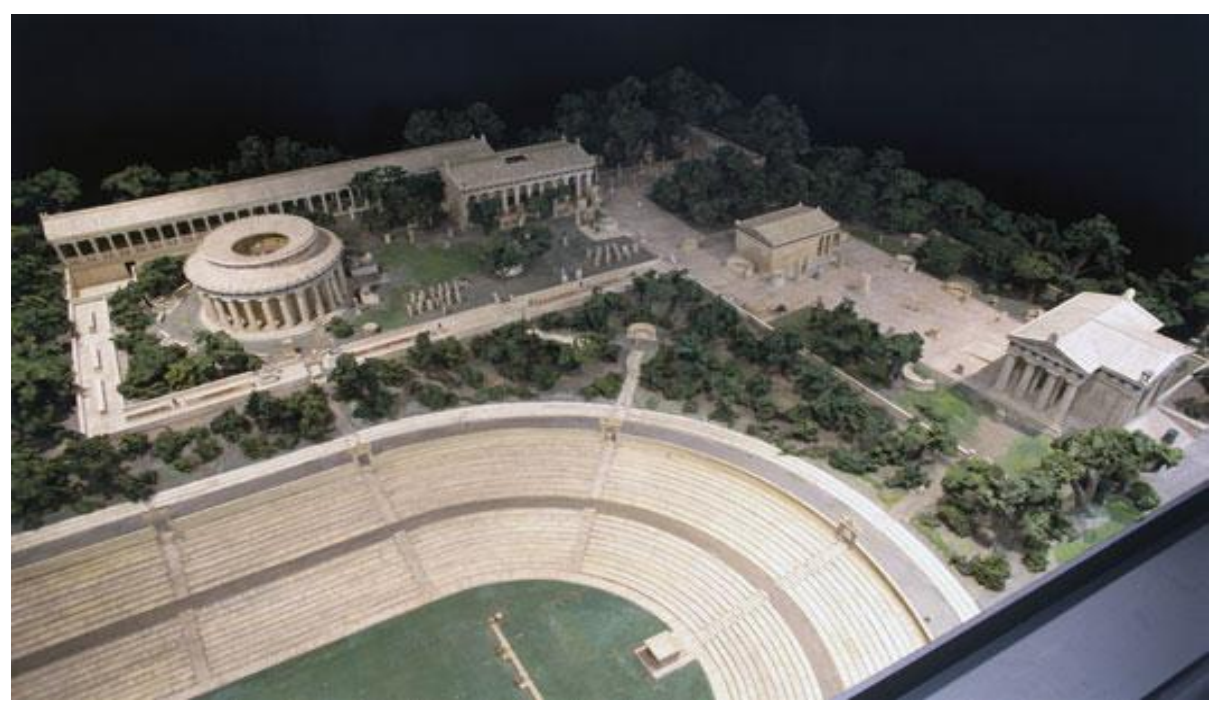

Fonte: Model of the Asklepeion at Epidauras, Greece, 1936. Disponível em: <http://www.sciencemuseum.org.uk/images/Io23/10284985.aspx>.

Fig. 2-Teatro do Santuário de Epidauro

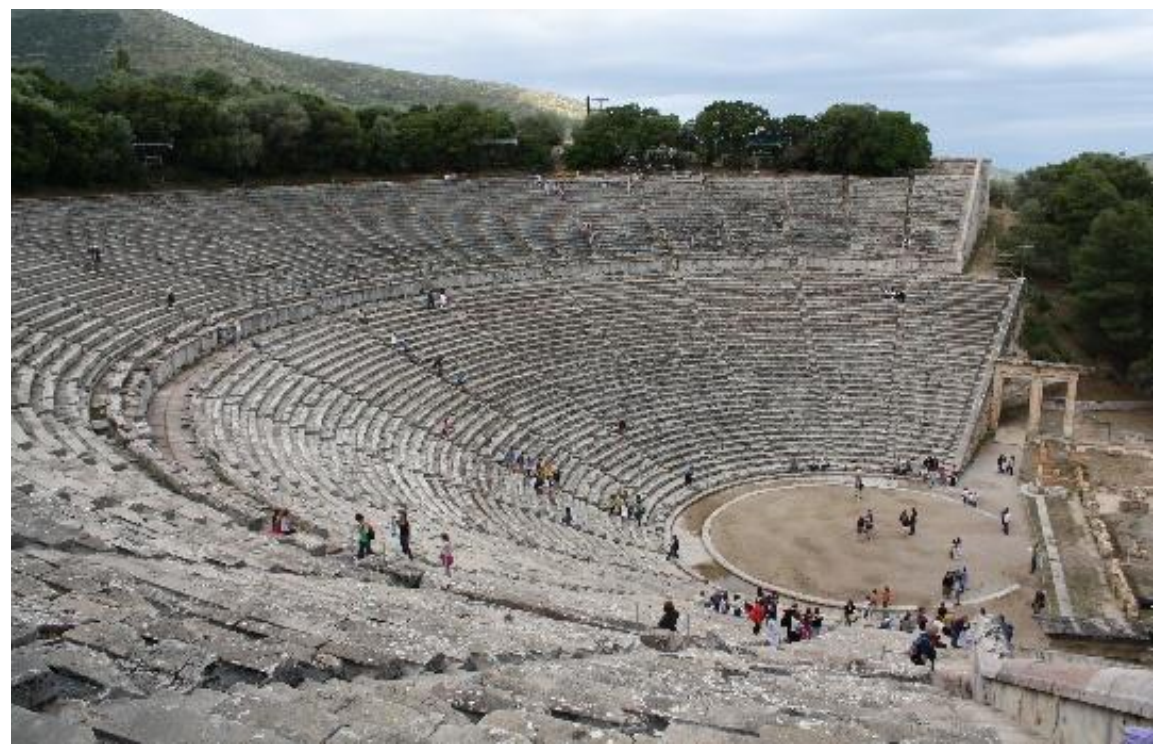

Fonte: Teatro do Santuário Asclepíade de Epidauro. Ancient History Encyclopedia. Disponível em <http://www.ancient.eu/epidaurus/>. 


\section{Fig.3- Asclépio curando}



Fonte: Baixo relevo, National Archeological Museum of Greece. Disponível em $<$ http://www.namuseum.gr/wellcome-en.html>.

Fig. 4- ex-votos do Asklepeion

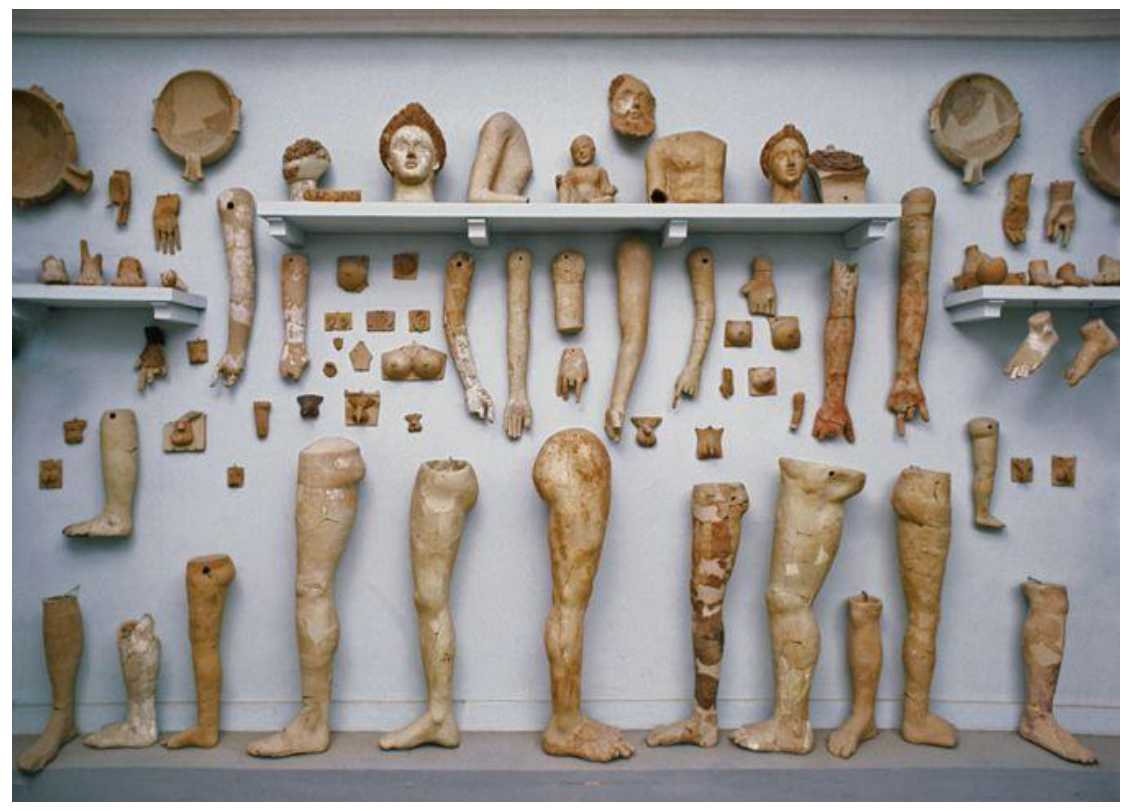

Fonte: Ex-votos deixados no Asklépeion de Epidauro. Disponível em <http://www.bbc.co.uk/schools/primaryhistory/ancient_greeks/gods_and_heroes/> . 
Fig. 4: Christus medicus, séc. V

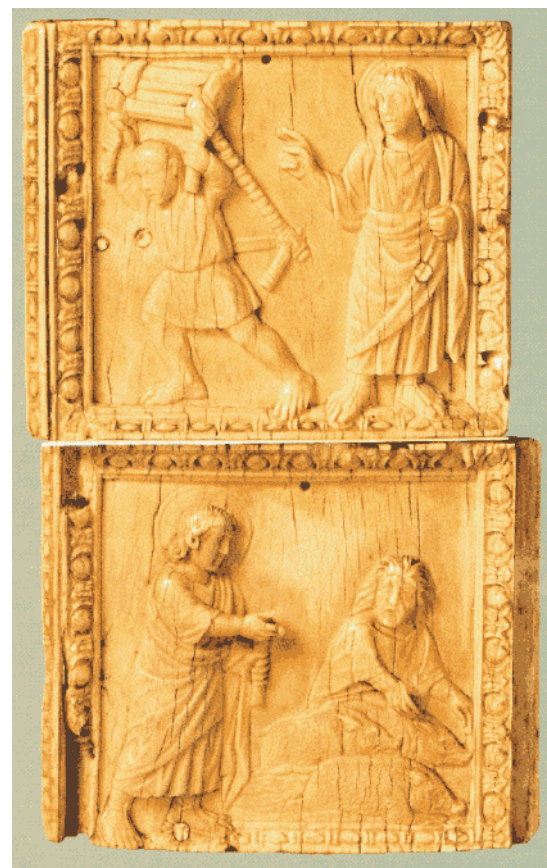

Fonte: Die Heilung eines Gichtbrüchigen (Mt 2, 10-12), na capa do trabalho de SCHOTT, 2004, p. 28-29.

Fig. 5 Christus medicus (980-993 dC)

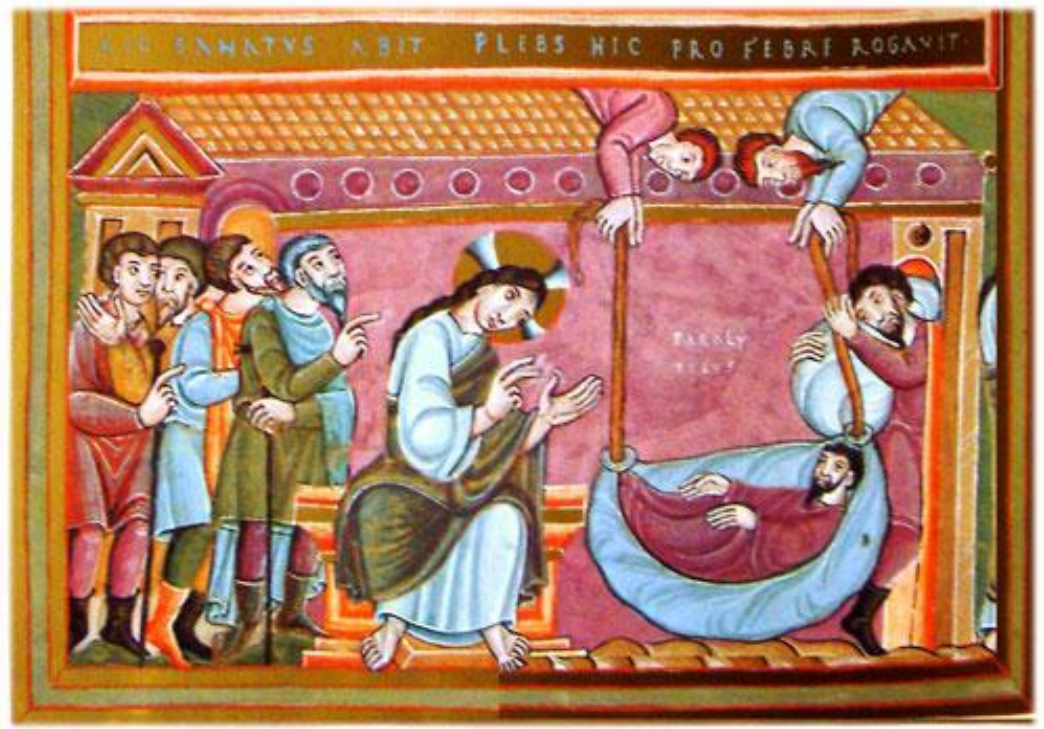

Fonte: Heilung des Gelähmten In Codex Aureus. Münchener DigitalisierungsZentrum Digitale Bibliothek und Bayerische SttatsBibliothek. Disponível em <https://www.bsbmuenchen.de/benutzung-und-service/lehrmaterialien-fuer-schulen/codex-aureus/ > . 